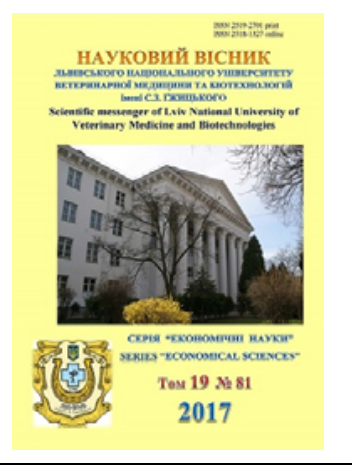

Науковий вісник Львівського національного університету ветеринарної медицини та біотехнологій імені С.3. Гжицького

Scientific Messenger of Lviv National University of Veterinary Medicine and Biotechnologies

doi:10.15421/nvlvet8105

ISSN 2519-2701 print

ISSN 2518-1327 online

http://nvlvet.com.ua/

УДК 631.3: 681.3

\title{
Алгоритм врахування кадрового забезпечення тваринницького підприсмства при математичному моделюванні впливу середовища на продуктивність тварин
}

\author{
Б.І. Козій ${ }^{1}$, О.І. Степанюк ${ }^{1}$, В.П. Новосад ${ }^{2}$ \\ astepanov69@ukr.net \\ ${ }^{1}$ Львівський національний університет ветеринарної медицини та біотехнологій імені С.3. Гюсицького, \\ вул. Пекарська, 50, м. Львів, 79010, Україна; \\ ${ }^{2}$ Львівський регіональний інститут державного управління Національної академї державного управління при \\ Президентові України, вул.Сухомлинського, 16, Львів, 79491, Україна
}

\begin{abstract}
При інтенсивному веденні певної галузі тваринництва варто пам'ятати, щзо лише здорова, належно утримана тварина може проявити максимальну продуктивність, яка зумовлена ї̈ спадковістю. Реальна продуктивність тварини буде дещо меншою від максимальної за рахунок несприятливого впливу факторів зовнішнього середовища. Оцінити такий вплив можна за допомогою коефіиієнта зниження продуктивності. Визначення величини такого коефіиієнта може здійснюватися иляхом його обчислення за допомогою математичних моделей та відповідних алгоритмів. До факторів, які впливають на продуктивність тварин, належать також кількість та рівень виконавської дисципліни працівників тваринництва. 3 урахуванням подальшого розвитку тваринництва потреба у висококваліфікованих кадрах та вимоги до них значно зросmymb.

В даній статті пропонується математична модель для кількісної оиінки впливу факторів, які враховують наявність кадрів і рівень виконавської дисципліни працівників підприємства, на продуктивність тварин та алгоритм реалізації такої оцінки засобами табличного процесора Exсеl. Для визначення дії кожного з факторів передбачено окремі сторінки книги електронних таблиць. Результати обчислень автоматично фіксуються в підсумковій таблиці оцінки впливу кадрового забезпечення твариннищького підприємства та дотримання вимог добробуту тварин на їх продуктивність.

Ключові слова: тварини, продуктивність, добробут тварин, кадрове забезпечення підприємства, виконавська дисципліна, математична модель, числові методи, табличний процесор.
\end{abstract}

\section{Алгоритм учета кадрового обеспечения животноводческого предприятия при математическом моделировании влияния среды на продуктивность животных}

\author{
Б.И. Козий ${ }^{1}$, О.І. Степанюк ${ }^{1}$, В.П. Новосад ${ }^{2}$ \\ astepanov69@ukr.net
}

1Львовский национальный университет ветеринарной медищины и биотехнологий имени С.3. Гжицкого, ул. Пекарская, 50, г. Львов, 79010, Украина;

${ }^{2}$ Львовский региональный институт государственного управления Национальной академии государственного управления при Президенте Украины, ул. Сухомлинского, 16, Львов, 79491, Украина

При интенсивном ведении определенной отрасли животноводства необходимо помнить, что только здоровое животное может проявить максимальную продуктивность, обусловленную его наследственностью. Реальная продуктивность животного будет несколько меньшей от максимальной за счет неблагоприятного влияния факторов внешней среды. Оие-

\section{Citation:}

Kozij, B., Stepanjuk, O., Novosad, V. (2017). Algorithm of incorporation a staffing of livestock enterprises by the mathematical design of influence of environment on the animal productivity. Scientific Messenger LNUVMB, 19(81), 32-36. 
нить такое влияние можно, используя коэффициент снижения продуктивности. Определение величины такого коэффичента может осуществляться при помощу математических моделей и соответствующих алгоритмов. К факторам, вплияюшим на продуктивность животных, относятся количество и уровень исполнительской дисциплины работников животноводства. 3 учетом дальнейшего развития животноводства потребность в высококвалифицированных кадрах и требования к ним значительно возрастут.

В данной статье предлагается математическая модель для количественной оченки влияния факторов, учитывающих наличие кадров и уровень исполнительской дисииплины работников предприятия, на продуктивность животньх и алгоритм реализации такой оченки средствами табличного процессора Ехсеl. Для определения действия каждого из факторов предусмотрены отдельные страницы книги электронных таблиц. Результаты вычислений автоматически фиксируются в итоговой таблице оченки влияния кадрового обеспечения животноводческого предприятия и соблюдения требований благосостояния животных на их продуктивность.

Ключевые слова: животные, продуктивность, благополучие животных, кадровое обеспечение предприятия, исполнительская дисииплина, математическая модель, числовые методы, табличный процессор.

\title{
Algorithm of incorporation a staffing of livestock enterprises by the mathematical design of influence of environment on the animal productivity
}

\author{
B. Kozij ${ }^{1}$, O. Stepanjuk ${ }^{1}$, V. Novosad ${ }^{2}$ \\ astepanov69@ukr.net \\ ${ }^{I}$ Stepan Gzhytskyi National University of Veterinary Medicine and Biotechnologies Lviv, \\ Pekarska Str., 50, Lviv, 79010, Ukraine; \\ ${ }^{2}$ Lviv Regional Institute of Public Administration National Academy of Public Administration, \\ Sukhomlynsky Str., 16, Lviv, 79491, Ukraine
}

By the intensive conducting of certain stock-raising industry it should be remembered that only a healthy, properly retained animal can show a burst productivity that is predefined by her heredity. The real productivity of an animal will be some less from maximal due to unfavorable influence of environmental factors. The estimation of such influence is possible by means of coefficient of the productivity decrease. Determination of size of such coefficient can be made by his calculation by means of mathematical models and corresponding algorithms. To the factors that influence on the productivity of animals belongs also a level of carrying out discipline of livestock workers. Taking into account further development of stock-raising the need for highly qualified personnel and requirements to them will grow considerably.

In this article a mathematical model is offered for the quantitative estimation of the influence of factors that take into account the presence of workers and level of carrying out discipline of workers in enterprise on the productivity of animals. Also the article offered an algorithm of realization of such estimation facilities by Excel.

For determination of each factors influence, separate pages of book of spreadsheets is envisaged. The results of calculations are automatically fixed in the final table of estimation of influence of the staffing of stock-raising enterprise and observance of requirements to the welfare of animals on their productivity.

Key words: animals, productivity, welfare of animals, staffing of enterprise, carrying out discipline, mathematical model, quantitative methods, tabular

Продуктивність сільськогосподарських тварин зазвичай залежить від їхнього генетичного потенціалу, від забезпеченості кормами та їх згодовуванням, від створення на фермах і комплексах відповідних умов утримання, що гарантують благополуччя ферми щодо незаразних та заразних хвороб. При інтенсивному веденні відповідної галузі тваринництва вартопам'ятати, що лише здорова, гарно утримана тварина може проявити максимальну продуктивність, яка обумовлена її спадковістю. Оскільки на здоров'я тварини впливають різноманітні фактори, виникає потреба створення методики врахування такого впливу.

В запропонованій раніше (Demtschuk et al., 2010) математичній моделі, за допомогою якої можна оцінити вплив різноманітних факторів на продуктивність тварин, вважається, що фактична продуктивність тварини $P_{\phi}$ може бути обчислена за формулою:

$$
P_{\phi}=P_{2} * \kappa_{3 n},
$$

де, $P_{2}$ - максимальна продуктивність тварини, що відповідає ії генетичному потенціалу; $\kappa_{3 n}-$ коефіцієнт зниження генетично обумовленої продуктивності внаслідок наявних умов утримання тварини.
Зазвичай значення цього коефіцієнт може коливатися в межах

$$
0<\kappa_{3 n}<=1
$$

i залежить від багатьох факторів, які можна об'єднати у такі групи: дотримання екологічних вимог, технологія і система утримання тварин, грунти, рослини, якість кормів, стан будівель, внутрішнього обладнання, механізмів, відповідність вибраного варіанту технології, захворюваність тварин стада, якість води та напування тварин, годівля, збалансованість раціонів, мікроклімат та внутрішній біоценоз, кадри, їхня кваліфікація, дотримання вимог добробуту тварин.

Кожна 3 цих груп факторів може бути оцінена в межах 5-бальної шкали: від «дуже добре» - 5, до «дуже погано» - 1

Своєю чергою, кожна 3 цих груп факторів може містити ряд складових, що впливають на кінцеву іiі оцінку, а отже, кількісна оцінка групи факторів повинна бути деякою інтегральною величиною, яка враховує оцінки складових.

Важливою умовою подальшого підвищення ефективності тваринництва - це забезпечення галузі необ- 
хідними кваліфікованими кадрами. Сучасне тваринництво висуває особливі вимоги до фахівців. Воно вимагає максимального використання досягнень науки, застосування різних передових методів роботи 3 тваринами. В (Kozij and Demtschuk, 2012) запропоновано математичну модель для оцінки впливу групи факторів кадрового забезпечення тваринницького підприємства та дотримання вимог добробуту тварин як групи факторів, які впливають на продуктивність цих тварин. До таких факторів відносяться:

- укомплектованість штату працівників підприємства;

- кількість працівників з вищою освітою;

- кількість працівників 3 середньою спеціальною освітою;

- кількість кваліфікованих працівників зі стажем роботи понад 5 років;

- рівень виконавської дисципліни працівників підприємства;

- наявність службових приміщень для працівників 3 належними санітарно-побутовими умовами;

- наявність якісного спецодягу та засобів особистої гігієни для працівників;

- дотримання графіку технологічного процесу експлуатації тварин;

- дотримання режиму годівлі та напування тварин;

- дотримання режиму моціону та відпочинку тварин.

Отже, маємо десять факторів, які дають змогу оцінити вплив кадрового забезпечення тваринницького підприємства та дотримання вимог добробуту тварин на їх продуктивність. Інтегральна оцінка $I O$ такого впливу може коливатися, відповідно до наших припущень, в межах від 5 («відмінно») до 1 («дуже погано»), тобто:

$$
1 \leq I O \leq 5
$$

3 іншого боку, оскільки на величину такої оцінки впливають перераховані вище фактори, можна записати:

$$
I O=I O_{\text {макс }} \cdot K_{\phi}
$$

де $I O_{\text {макс }}=5$ - максимальне значення інтегральної оцінки впливу кадрового забезпечення тваринницького підприємства та дотримання вимог добробуту тварин на їх продуктивність;

$K_{\phi}-$ коефіцієнт зменшення IO за рахунок того, що окремі фактори (або усі фактори) не відповідають вимогам. Очевидно, що

$$
0<K_{\phi} \leq 1 .
$$

Кожний з наведених вище факторів можна оцінити за такими параметрами:

- задане номінальне числове значення $-A_{н i}$, де $i=$ $1,2, \ldots, 10$ (наприклад, для першого фактора - повна укомплектованість штату працівників даного підприємства, яка необхідна для його повноцінного функціонування);

- реальне числове значення - $A_{p i}$ (реальна наявна кількість працівників).

Очевидно, що вплив відхилення кожного з факторів від заданого стандарту на інтегральну оцінку може бути більш або менш суттєвим. Тому використаємо поняття ваги кожного фактора $-\boldsymbol{\sigma}_{\boldsymbol{q}}$, кожний з яких буде коливатися в межах:

$$
0<B_{\phi i}<1 \quad(i=1,2, \ldots, 10) .
$$

Сумарна вага усіх факторів, очевидно, рівна 1:

$$
\sum b_{\phi i}=1 \quad(i=1,2, \ldots, 10) \text {. }
$$

Очевидно, що на зменшення інтегральної оцінки впливають усі фактори даної групи. Тому можна записати:

$$
K_{\phi}=\kappa_{\phi 1} \cdot \kappa_{\phi 2} \cdot \kappa_{\phi 3} \cdot \kappa_{\phi 4} \cdot \kappa_{\phi 5} \cdot \kappa_{\phi 6} \cdot \kappa_{\phi 7} \cdot \kappa_{\phi 8} \cdot \kappa_{\phi 9} \cdot \kappa_{\phi 10},
$$

де, $\kappa_{\phi i}-$ коефіцієнт зменшення $I O$ за рахунок $i$ - го фактора $(i=1,2, \ldots, 10)$.

Оскільки для кожного фактору величина коефіцієнта $\kappa_{\phi i}$ залежить від відносної різниці номінального та реального значення фактора, то з урахуванням ваги фактора можна записати:

$$
\kappa_{\phi i}=1-\left(A_{H i}-A_{p i}\right) / A_{H i} \cdot \kappa_{\phi i} .
$$

На основі запропонованої математичної моделі розроблено програму обчислення та аналізу впливу факторів кадрового забезпечення тваринницького підприємства та дотримання вимог добробуту тварин на продуктивність цих тварин засобами табличного процесора MS Excel. Вигляд електронної таблиці 3 відповідними розрахунковими формулами наведено на рис.1. Тут у стовпчику «Норма» - бажані (номінальні) числові значення факторів, а у стовпчику «Наявна кількість» - реальні величини цих факторів. Вважається, що усі фактори мають однакову вагу (на рис. 1 це величина 0,1 у стовпчику «Вага фактору»). Їх сума завжди доровнює 1 (клітина F14). Величина коефіцієнта зменшення $I O K_{\phi}$ обчислюється у клітині G15, а сама величина $I O$ обчислюється у клітині D16.

Запропоновану в (Kozij and Demtschuk, 2012) методику оцінки впливу кадрового забезпечення тваринницького підприємства та дотримання вимог добробуту тварин на їхню продуктивність доцільно, на нашу думку, доповнити сукупністю математичних моделей, які дозволять повніше врахувати вплив окремих факторів на результат обчислень.

Йдеться про фактори «Укомплектованість штату працівників підприємства» та «Рівень виконавської дисципліни працівників підприємства» (див. рис. 1, рядки 4 і 8). Для їх аналізу доцільно застосувати методику, яка запропонована в (Nikitin et al., 1996). Виходячи із цієї методики можна обчислити норму укомплектованості штату працівників підприємства за формулою:

$$
H=\left(T_{1} A_{1}+T_{2} A_{2}+\ldots+T_{n} A_{n}\right) /\left(60 *\left(T_{p}-T_{p n 3}-T_{p 6 o}\right),\right.
$$

де $T_{i}$, - норми оперативного часу на виконання відповідних робіт, хв;

$A_{i}-$ річні об'єми робіт за їх видами $(\mathrm{i}=1,2, \ldots \mathrm{n})$;

$T_{p}$ - річний об'єм часу одного працівника, год;

$T_{p n з}-$ річна норма часу на підготовчі та заключні роботи, год;

$T_{p в о}-$ річна норма часу на відпочинок та особисті потреби працівника, год.

Отже, значення норми укомплектованості штату працівників підприємства (клітина С4 на рис. 1) можна обчислити за формулою (8). 


\begin{tabular}{|c|c|c|c|c|c|c|c|}
\hline & $\mathrm{A}$ & $\mathrm{B}$ & $\mathrm{C}$ & $\mathrm{D}$ & $E$ & $\mathrm{~F}$ & G \\
\hline 1 & \multicolumn{7}{|c|}{ Фактори, які враховують наявність кадрів, їх кваліфікацію, дотримання вимог добробуту тварин } \\
\hline 2 & & & & & & & \\
\hline 3 & Фактори & $\begin{array}{c}\text { Наявна } \\
\text { кількість }\end{array}$ & Норма & Різниця & \begin{tabular}{|c|} 
Відносна \\
різниця
\end{tabular} & $\begin{array}{c}\text { Вагомість } \\
\text { фактору }\end{array}$ & $\begin{array}{c}\text { Коефріцієнт } \\
\text { впливу }\end{array}$ \\
\hline 4 & $\begin{array}{l}\text { Укомплектованість штату працівників } \\
\text { підприємства }\end{array}$ & 8 & 10 & $=\mathrm{C} 4-\mathrm{B} 4$ & $=\mathrm{D} 4 / \mathrm{C} 4$ & 0,1 & $=1-\mathrm{E} 4{ }^{*} \mathrm{~F} 4$ \\
\hline 5 & Кількість працівників з вищою освітою & 4 & 4 & $=\mathrm{C} 5-\mathrm{B} 5$ & $=\mathrm{D} 5 / \mathrm{C} 5$ & 0,1 & $=1-\mathrm{E} 5{ }^{\star} \mathrm{F} 5$ \\
\hline 6 & $\begin{array}{l}\text { Кількість працівників з середньою } \\
\text { спеціальною освітою }\end{array}$ & 3 & 4 & $=\mathrm{C} 6-\mathrm{B} 6$ & $=\mathrm{D} 6 / \mathrm{C} 6$ & 0,1 & $=1-E 6^{*} F 6$ \\
\hline 7 & $\begin{array}{l}\text { Кількість кваліфікованих працівників із } \\
\text { стажем роботи більше 5-ти років; }\end{array}$ & 2 & 5 & $=\mathrm{C} 7-\mathrm{B} 7$ & $=\mathrm{D} 7 / \mathrm{C} 7$ & 0,1 & $=1-\mathrm{E} 7^{\star} \mathrm{F} 7$ \\
\hline 8 & Рівень виконавської дисципліни працівників & 15 & 20 & $=\mathrm{C} 8-\mathrm{B} 8$ & $=\mathrm{D} 8 / \mathrm{C} 8$ & 0,1 & $=1-E 8^{*} F 8$ \\
\hline 9 & $\begin{array}{l}\text { Наявність службових приміщень для } \\
\text { працівників } 3 \text { належними санітарно- } \\
\text { побутовими умовами; }\end{array}$ & 4 & 5 & $=\mathrm{C} 9-\mathrm{B} 9$ & $=\mathrm{D} 9 / \mathrm{C} 9$ & 0,1 & $=1-E 9 * F 9$ \\
\hline 10 & $\begin{array}{l}\text { Наявність якісного спецодягу та засобів } \\
\text { особистої гігієни для працівників; }\end{array}$ & 8 & 10 & $=\mathrm{C} 10-\mathrm{B} 10$ & $=\mathrm{D} 10 / \mathrm{C} 10$ & 0,1 & $=1-\mathrm{E} 10^{*} \mathrm{~F} 10$ \\
\hline 11 & $\begin{array}{l}\text { Дотримання графіку технологічного процесу } \\
\text { експлуатації тварин }\end{array}$ & 10 & 10 & $=\mathrm{C} 11-\mathrm{B} 11$ & $=\mathrm{D} 11 / \mathrm{C} 11$ & 0,1 & $=1-\mathrm{E} 11^{\star} \mathrm{F} 11$ \\
\hline 12 & $\begin{array}{l}\text { Дотримання режиму годівлі та напування } \\
\text { тварин }\end{array}$ & 8 & 10 & $=\mathrm{C} 12-\mathrm{B} 12$ & $=\mathrm{D} 12 / \mathrm{C} 12$ & 0,1 & $=1-\mathrm{E} 12^{*} \mathrm{~F} 12$ \\
\hline 13 & $\begin{array}{l}\text { Дотримання режиму моціону та відпочинку } \\
\text { тварин }\end{array}$ & 5 & 10 & $=\mathrm{C} 13-\mathrm{B} 13$ & $=\mathrm{D} 13 / \mathrm{C} 13$ & 0,1 & $=1-\mathrm{E} 13^{*} \mathrm{~F} 13$ \\
\hline 14 & & & & & сума & $=$ CYMMM(F4:F13) & \\
\hline 15 & & & & & & $\begin{array}{l}\text { Сумарний } \\
\text { коефіцієнт }\end{array}$ & 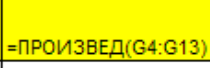 \\
\hline 16 & & & Результат & $=5^{*} \mathrm{G} 15$ & & & \\
\hline
\end{tabular}

Рис. 1. Вигляд електронної таблиці для обчислення коефіцієнта впливу факторів кадрового забезпечення тваринницького підприємства та дотримання вимог добробуту тварин на продуктивність цих тварин

Фактичне та нормативне значення фактору рівень виконавської дисципліни працівників підприємства можна обчислити, виходячи 3 наведених у (Nikitin et al., 1996) рекомендацій, таким чином.

Нехай позначимо:

$T_{p д}$ - тривалість робочого дня, хв;

$T_{\text {oн }}$ - нормативні затрати часу на оперативну роботу, хв;

$T_{o \phi}-$ фактичні затрати часу на оперативну роботу, $\mathrm{XB}$;

$T_{n з}$ - час на підготовчу та заключну роботу, хв;

$T_{p n}$ - час на регламентовану перерву, хв;

$T_{н n}-$ час, витрачений на нерегламентовані перерви, хв;

$T_{i p}-$ час, витрачений на інші види робіт, хв.

Тоді:

$$
\begin{aligned}
& T_{o H}=T_{p \partial}-T_{n 3}-T_{p n} ; \\
& T_{o \phi}=T_{p \partial}-T_{n 3}-T_{p n}-\left(T_{н n}+T_{i p}\right),
\end{aligned}
$$$$
\text { або } \quad T_{o \phi}=T_{o н}-\left(T_{H n}+T_{i p}\right) \text {. }
$$

Виходячи з формул (9), (10), можна обчислити величину коефіцієнт раціонального використання часу оперативної роботи $K_{o p}$ :

$$
K_{o p}=T_{о \phi} / T_{о н} .
$$

Очевидно, що у випадку, коли працівники підприємства не витрачають час на нерегламентовані перерви та на інші види робіт, тобто, коли

$$
T_{\text {нn }}+T_{i p}=0
$$

то $K_{o p}=1$ або $K_{o p}=100 \%$

В іншому випадку $K_{o p}<1$, або $K_{o p}<100 \%$

Тому, величиною $K_{o p}$ можна оцінювати рівень виконавської дисципліни працівників підприємства (див. рядок 8 рис. 1). Тоді норма цього фактору дорівнює 1, або 100\% (клітина С8), а фактичний рівень можна обчислити за формулою (11) (клітина $\mathbf{B 8}$ ).
Для практичної реалізації запропонованої методики доцільно доповнити книгу електронних таблиць, яка містить програму обчислення впливу факторів кадрового забезпечення тваринницького підприємства та дотримання вимог добробуту тварин на їхню продуктивність, новими сторінками 3 програмами, які дозволяють обчислити норми укомплектованості штату працівників підприємства та рівень їхньої виконавської дисципліни.

На рис. 2 зображено вигляд електронної таблиці 3 формулами для обчислення норми укомплектованості штату працівників тваринницького підприємства. Вхідну інформація, яка необхідна для виконання обчислень, слід увести у відповідні клітини, які затінені сірим кольором. Результат обчислень одержимо в клітині B11. В подальшому цей результат потрібно використати для заповнення клітини С4 основної електронної таблиці (див. рис. 1).

На рис. 3 зображено вигляд електронної таблиці 3 формулами для обчислення рівня виконавської дисципліни працівників тваринницького підприємства. Вхідну інформація, яка необхідна для виконання обчислень, слід увести у відповідні клітини, які затінені сірим кольором. Результат обчислень одержимо в клітині В10. В подальшому цей результат потрібно використати для заповнення клітини В8 основної електронної таблиці (див. рис. 1). В даному прикладі (рис. 3) вважалося, що на підприємстві штат працівників складає чотири особи, а для обчислення коефіцієнта раціонального використання ними оперативної роботи беруться усереднені значення нормативного та фактичного часу виконання роботи (стовпчик $\mathbf{F}$ ). 


\begin{tabular}{|c|c|c|c|c|c|c|c|}
\hline & A & $\mathrm{B}$ & $\mathrm{C}$ & $\mathrm{D}$ & $E$ & $\mathrm{~F}$ & G \\
\hline 1 & \multirow{2}{*}{ Параметри } & \multicolumn{5}{|c|}{ Види робіт } & \multirow{2}{*}{ Разом } \\
\hline 2 & & 1 & 2 & 3 & 4 & 5 & \\
\hline 3 & $\begin{array}{l}\text { Норми оперативного часу на виконання } \\
\text { виду роботи Т }\end{array}$ & & & & & & \\
\hline 4 & Річний об'єм робіт за їх видами А & & & & & & \\
\hline 5 & Добуток T*A & $=\mathrm{B} 3^{*} \mathrm{~B} 4$ & $=\mathrm{C} 3^{*} \mathrm{C} 4$ & $=\mathrm{D} 3^{*} \mathrm{D} 4$ & $=\mathrm{E} 3^{\star} \mathrm{E} 4$ & $=\mathrm{F} 3^{*} \mathrm{~F} 4$ & $=\mathrm{CYMM}(\mathrm{B} 5: \mathrm{F} 5)$ \\
\hline \multicolumn{8}{|r|}{ 然 } \\
\hline 7 & $\begin{array}{l}\text { Річний об'єм робочого часу одного } \\
\text { працівника }\end{array}$ & & & & & & \\
\hline 8 & Річна норма часу на підготовчі роботи & & & & & & \\
\hline 9 & $\begin{array}{l}\text { Річна норма часу на відпочинок та } \\
\text { особисті потреби }\end{array}$ & & & & & & \\
\hline \multicolumn{8}{|c|}{10} \\
\hline 11 & $\begin{array}{l}\text { Нома чисельності прцівників } \\
\text { тваринницького підприємства }\end{array}$ & $=\mathrm{G} 5 /\left(60^{*}\right.$ & B7-B8-B9)) & & & & \\
\hline
\end{tabular}

Рис. 2. Вигляд електронної таблиці для обчислення норми укомплектованості штату працівників тваринницького підприємства

\begin{tabular}{|c|c|c|c|c|c|c|}
\hline & A & $B$ & C & D & $E$ & $\mathrm{~F}$ \\
\hline 1 & \multirow{2}{*}{ Часові параметри } & \multicolumn{4}{|c|}{ Працівники } & \multirow{2}{*}{ Разом } \\
\hline 2 & & 1 & 2 & 3 & 4 & \\
\hline 3 & Тривалість робочого дня & & & & & \\
\hline 4 & Час на підготовчі роботи & & & & & \\
\hline 5 & Час на регламентовані перерви & & & & & \\
\hline 6 & Затрати часу на нерегламентовані перерви & & & & & \\
\hline 7 & Затрати часу на виконання інших робіт & & & & & \\
\hline 8 & Нормативний час на оперативну роботу & $=\mathrm{B} 3-\mathrm{B} 4-\mathrm{B} 5$ & $=\mathrm{C} 3-\mathrm{C} 4-\mathrm{C} 5$ & $=$ =D3-D4-D5 & $=\mathrm{E} 3-\mathrm{E} 4-\mathrm{E} 5$ & $=\mathrm{CP} 3 \mathrm{HA} 4 \mathrm{~A}(\mathrm{~B} 8: \mathrm{E} 8)$ \\
\hline 9 & Фактичний час на оперативну роботу & $=\mathrm{B} 8-\mathrm{B} 6-\mathrm{B} 7$ & $=\mathrm{C} 8-\mathrm{C} 6-\mathrm{C} 7$ & =D8-D6-D7 & $=\mathrm{E} 8-\mathrm{E} 6-\mathrm{E} 7$ & $=\mathrm{CP} 3 \mathrm{HAЧA}(\mathrm{B} 9: \mathrm{E} 9)$ \\
\hline 10 & $\begin{array}{l}\text { Коесріцієнт раціонального використання } \\
\text { часу оперативної роботи }\end{array}$ & $=F 9 / F 8$ & & & & \\
\hline
\end{tabular}

Рис. 3. Вигляд електронної таблиці для обчислення рівня виконавської дисципліни працівників тваринницького підприємства

Таким чином, використовуючи запропоновану методику для обчислення норми укомплектованості штату працівників тваринницького підприємства та рівня виконавської дисципліни цих працівників, можна суттєво вдосконалити алгоритм визначення бальної оцінки впливу кадрового забезпечення тваринницького підприємства та дотримання вимог добробуту на продуктивність тварин.

\section{Бібліографічні посилання}

Demtschuk, M.V., Kozenko, O.V., Kozij, B.I., Knysuk, P.V. (2010). Do metodyky vyvczennja vplyvu kompleksu tschynnykiv seredovytscha na funkcionalnyj stan organizmu abo s stada tvaryn. Naukovyj visnyk LNUVMBT. 12, 162-173 (in Ukrainian).

Kozij, B.I., Demtschuk, M.V. (2012). Matematytschna model ocinky vplyvu kadrovoho zabezpetschennja nvarynnyckyh pidpryjemstv ta dotrymannja vymoh dobrobutu tvaryn na jich produktyvnict. Naukovyj visnyk LNUVMBT. 14, 31-37 (in Ukrainian).

Nikitin, I.N., Shaichamanov, M.Ch., Voskobojnyk, V.F. (1996). Organizacija I ekonomika veterinarnoho dela. Kolos (in Russian). 